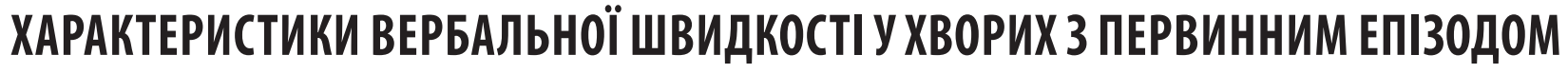 БІПОЛЯРНОГО АФЕКТИВНОГО РОЗЛАДУ
}

\author{
Ю. І. Мисула
}

\begin{abstract}
Мисула
Юрій Ігорович

Тернопільський національний медичний університет ім. І.Я. Горбачевського М03

України, вул. Майдан Волі, 1, м. Тернопіль, Україна, 46001

yuramysula@gmail.com; 0RCID ID: 0000-0001-7443-5304
\end{abstract}

\begin{abstract}
Проведено дослідження з використанням тесту вербальної швидкості 153 хворих з первинним епізодом біполярного афективного розладу: 3 переважанням депресивної симптоматики (44 чоловіка і 75 жінок), з переважанням маніакальної симптоматики (15 чоловіків і 8 жінок) та з одночасною наявністю депресивної та маніакальної симптоматики або зі швидкою зміною фаз (6 чоловіків і 5 жінок).

Виявлено значне погіршення виконання тесту у хворих з депресивним варіантом щодо фонетичної і семантичної вербальної швидкості: середня кількість слів на літеру «К» за 60 сек. у всіх хворих 14,1 2,7 слів, у чолові-

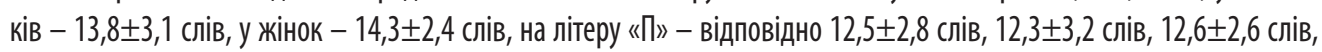

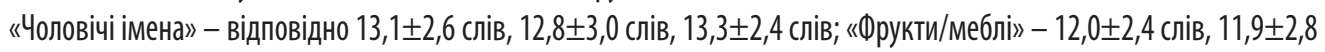

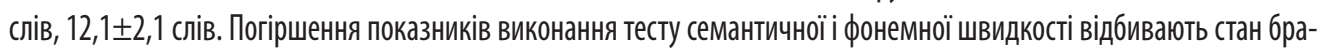
дипсихізму, притаманний хворим з депресивним варіантом, при якому виявляються сповільнений темп мислення, труднощі концентрації уваги, моторна загальмованість, погіршення операціональних можливостей, швидка виснажуваність і зниження енергетичного потенціалу. У хворих з маніакальним варіантом висока швидкість виконання тесту нівелюється значною кількістю помилок внаслідок хаотичності ментальної діяльності, нестійкості і розсіювання

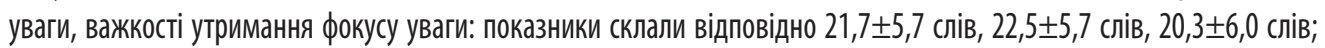
$20,3 \pm 5,6$ слів, 21,1 $\pm 5,5$ слів, 19,0 05,9 слів; 20,5 $\pm 5,4$ слів, 21,2 25,2 слів, 19,1 $\pm 5,7$ слів; 19,5 $\pm 5,4$ слів, 20,2 $\pm 5,2$ слів, $18,1 \pm 5,7$ слів. У хворих зі змішаним варіантом показники вербальної швидкості знижені за рахунок впливу складної

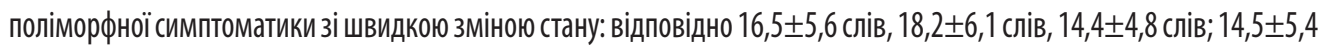

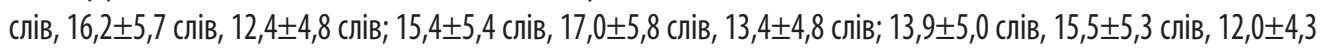
слів. Розбіжності у показниках за всіма субтестами у всіх групах між чоловіками та жінками статистично незначущі $(p>0,05)$.
\end{abstract}

Ключові слова: біполярний афективний розлад, первинний епізод, вербальна швидкість. 


\section{Вступ}

Біполярний афективний розлад (БАР) $€$ однією 3 найбільш актуальних проблем сучасної психіатричної науки і практики. Захворювання на БАР відрізняється хронічним перебігом, значною коморбідністю, залежністю від вживання психоактивних речовин, підвищеною смертністю від супутніх соматичних захворювань і нещасних випадків, а також високим рівнем суїцидальної активності хворих [1-4].

Надзвичайно важливим для своєчасного і якісного лікування БАР $€$ рання діагностика захворювання на ініціальному етапі. Первинні прояви БАР виявляються за кілька років до синдромально оформленого розладу, при цьому система первинної оцінки та прогнозування БАР на ранніх етапах $є$ недосконалою [5-7]. Дослідження останніх років показали, що у значній частині випадків від первинних проявів до встановлення діагнозу БАР може проходити декілька років, при тому, що характер подальшого розвитку захворювання на БАР значною мірою зумовлений особливостями первинного епізоду (ПЕ) захворювання, що можуть розглядатися в якості предикторів важкості захворювання, функціональних наслідків та відповіді на лікування [8]. Однак, вирішення задачі раннього виявлення і прогнозування БАР пов'язане зі значними труднощами у зв'язку з недостатньою дослідженістю ініціальних характеристик захворювання і низькою прогностичною цінністю існуючих предикторів, що вимагає удосконалення інструментів продромальної ідентифікації [9].

Останнім часом особлива увага дослідників прикута до вивчення особливостей когнітивного функціонування при БАР. Розлади когнітивної функції розглядаються як важлива складова комплексних психопатологічних змін при БАР, вони виявляються як в маніакальній і депресивній фазі, так і в період інтермісії [10-12]. При БАР виявляється широкий спектр когнітивних розладів, серед яких порушення формальних характеристик мислення та його змісту, виконавських функцій, уваги та пам'яті [13-15].

Водночас, сьогодні відчувається гострий дефіцит наукових досліджень, спрямованих на вивчення особливостей когнітивного функціонування при ПЕ БАР, що утруднює розробку сучасних ефективних діагностичних, лікувально-реабілітаційних та профілактичних заходів.

\section{Мета дослідження}

Дослідити характеристики вербальної швидкості при первинному епізоді біполярного афективного розладу з урахуванням гендерного фактору і клінічного варіанту.

\section{Матеріали і методи дослідження}

3 дотриманням принципів біомедичної етики на підставі інформованої згоди нами було клінічно обстежено
153 хворих (65 чоловіків та 88 жінок) з первинним епізодом БАР, які перебували на лікуванні у Тернопільській обласній психоневрологічній лікарні у період 2011-2016 років.

Серед обстежених чоловіків і жінок нами було виділено по три групи в залежності від клінічного варіанту перебігу ПЕ БАР: з переважанням депресивної симптоматики (депресивний варіант), чисельністю 119 осіб (середній вік $21,4 \pm 6,4$ років (медіана 19,0 років, інтерквартильний діапазон 17,0-23,0 років), середній вік звернення за медичною допомогою 21,5 $\pm 6,4$ років (19,0 років, 17,0-23,0 років): 44 чоловіків (середній вік відповідно $20,9 \pm 6,3$ років (18,0 років, $17,0-23,0$ років), і 21,0 26,2 років (18,0 років, $17,0-23,5$ років) та 75 жінок (середній вік відповідно 21,7士6,5 років (19,0 років, 18,0-23,0 років) і $21,8 \pm 6,5$ років (19,0 років, $18,0-23,0$ років); 3 переважанням маніакальної або гіпоманіакальної симптоматики (маніакальний варіант), чисельністю 23 особи (середній вік відповідно $20,5 \pm 7,5$ років (18,0 років, 17,0 20,0 років), i $20,6 \pm 7,6$ років (18,0 років, $17,0-20,0$ років)): 15 чоловіків (середній вік відповідно 19,2 23,8 років (18,0 років, $17,0-20,0$ років) і $19,2 \pm 3,8$ років (18,0 років, 17,0-20,0 років)) та 8 жінок (середній вік відповідно $23,1 \pm 11,8$ років (19,5 років, $18,5-20,5$ років) і $23,1 \pm 11,8$ років (19,5 років, $18,5-20,5$ років)), та 3 одночасною наявністю депресивної та маніакальної симптоматики або зі швидкою зміною фаз (змішаний варіант), чисельністю 11 осіб (середній вік 21,4 45,4 років (19,0 років, 18,0-26,0 років), і 21,6 05,2 років (19,0 років, $18,0-26,0$ років)): 6 чоловіків (середній вік відповідно 20,8 26,7 років $(18,5$ років, $17,0-21,0$ років) і $21,2 \pm 6,4$ років ( 18,5 років, 18,0 21,0 років)) та 5 жінок (середній вік відповідно 22,2 24,0 років (20,0 років, $19,0-26,0$ років) і $22,2 \pm 4,0$ років $(20,0$ років, 19,0-26,0 років).

0бстеження проводилося за допомогою тесту вербальної швидкості. Тест складався 3 двох частин: для оцінки семантичної швидкості та для оцінки вербальної швидкості. Семантична швидкість (швидкість категорії) оцінювалася за здатністю обстежуваного створювати максимальну кількість унікальних слів у семантичній категорії (кількість слів, що належать до категорії «Чоловічі імена» та «Фрукти або меблі»), а фонемна швидкість (літерна швидкість) - за здатністю створювати максимальну кількість слів, що починаються 3 даної літери (у нашому тесті - літери «К» і «П»). На виконання тесту відводилося 60 секунд.

Статистичний аналіз проведено 3 використанням непараметричного тесту Манна-Уїтні. Прийнятним вважався рівень статистичної значущості розбіжностей понад 95,0\% $(p<0,05)$. 


\section{Результати дослідження та їх обговорення}

Дослідження особливостей когнітивного функціонування хворих 3 ПЕ БАР 3 різними клінічними варіантами 3 використанням тесту вербальної швидкості виявило ряд особливостей (табл. 1).

У хворих з депресивним варіантом ПЕ БАР було виявлено значне погіршення виконання тесту як щодо фонетичної вербальної швидкості (називання слів, що починаються на певну літеру абетки), так і щодо семантичної вербальної швидкості (називання слів, що належать до певної семантичної категорії).
Показники фонетичної вербальної швидкості у хворих $з$ депресивним варіантом ПЕ БАР $\epsilon$ низькими: середня кількість слів на літеру «К» за 60 сек. у всіх хворих

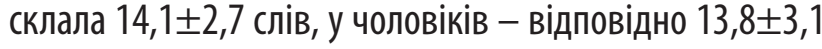
слів, у жінок - 14,3 22,4 слів. Середня кількість слів на літеру «П» склала у всіх хворих 12,5 22,8 слів, у чолові-

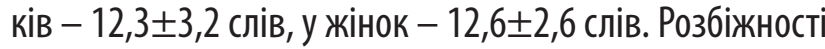
у показниках між чоловіками та жінками за фонетичною вербальною швидкістю статистично незначущі ( $p>0,05)$.

Аналогічно, у хворих з депресивним варіантом були виявлені низькі показники, що характеризують семанТаблиия 1

\section{Кількісні характеристики показників за тестом вербальної швидкості у обстежених хворих} з урахуванням статі та клінічного варіанту ПЕ БАР

\begin{tabular}{|c|c|c|c|c|c|c|c|c|c|c|}
\hline \multirow{2}{*}{\multicolumn{2}{|c|}{ Показник }} & \multicolumn{8}{|c|}{ Показник $\left(\mathrm{M} \pm \mathrm{m} / \mathrm{Me}\left(\mathrm{Q}_{25}-\mathrm{Q}_{75}\right)\right.$} & \multirow{2}{*}{$\mathrm{p}$} \\
\hline & & \multicolumn{3}{|c|}{ Разом } & \multicolumn{2}{|c|}{ Чоловіки } & \multicolumn{3}{|c|}{ Жінки } & \\
\hline \multicolumn{11}{|c|}{ Депресивний варіант ПЕ БАР } \\
\hline \multicolumn{2}{|l|}{ Кількість слів на літеру «К» } & \multicolumn{3}{|c|}{$14,1 \pm 2,7 / 14,0(13,0-15,0)$} & \multicolumn{2}{|c|}{$13,8 \pm 3,1 / 14,0(12,0-15,5)$} & \multicolumn{3}{|c|}{$14,3 \pm 2,4 / 14,0(13,0-15,0)$} & $>0,05$ \\
\hline \multicolumn{2}{|l|}{ Кількість слів на літеру «П» } & \multicolumn{3}{|c|}{$12,5 \pm 2,8 / 12,0(11,0-15,0)$} & \multicolumn{2}{|c|}{$12,3 \pm 3,2 / 12,0(10,5-15,0)$} & \multicolumn{3}{|c|}{$12,6 \pm 2,6 / 12,0(11,0-14,0)$} & $>0,05$ \\
\hline \multicolumn{2}{|l|}{ Кількість слів «Чоловічі імена» } & \multicolumn{3}{|c|}{$13,1 \pm 2,6 / 13,0(12,0-14,0)$} & \multicolumn{2}{|c|}{$12,8 \pm 3,0 / 13,0(11,0-14,5)$} & \multicolumn{3}{|c|}{$13,3 \pm 2,4 / 13,0(12,0-14,0)$} & $>0,05$ \\
\hline \multicolumn{2}{|l|}{ Кількість слів «Фрукти/меблі» } & \multicolumn{3}{|c|}{$12,0 \pm 2,4 / 12,0(11,0-14,0)$} & \multicolumn{2}{|c|}{$11,9 \pm 2,8 / 12,0(10,5-14,0)$} & \multicolumn{3}{|c|}{$12,1 \pm 2,1 / 12,0(11,0-13,0)$} & $>0,05$ \\
\hline \multicolumn{11}{|c|}{ Маніакальний варіант ПЕ БАР } \\
\hline \multicolumn{2}{|l|}{ Кількість слів на літеру «К» } & \multicolumn{2}{|c|}{$21,7 \pm 5,7 / 21,0(18,0-27,0)$} & \multicolumn{3}{|c|}{$22,5 \pm 5,7 / 21,0(19,0-28,0)$} & \multicolumn{3}{|c|}{$20,3 \pm 6,0 / 18,5(16,0-24,5)$} & $>0,05$ \\
\hline \multicolumn{2}{|l|}{ Кількість слів на літеру «П» } & \multicolumn{2}{|c|}{$20,3 \pm 5,6 / 20,0(17,0-25,0)$} & \multicolumn{3}{|c|}{$21,1 \pm 5,5 / 20,0(18,0-26,0)$} & & $0 \pm 5,9 / 17,5$ & $0-23,5)$ & $>0,05$ \\
\hline Кількість слів «Чоловічі імена» & & $20,5 \pm 5$, & $20,0(17,0$ & 21,2 & $, 2 / 20,0(18$ & $26,0)$ & & $1 \pm 5,7 / 17,5$ & $0-23,5)$ & $>0,05$ \\
\hline Кількість слів «Фрукти/меблі» & & $19,5 \pm 5$, & $19,0(16,0$ & 20,2 & $, 2 / 19,0(17$ & $25,0)$ & & $1 \pm 5,7 / 16,5$ & $0-22,5)$ & $>0,05$ \\
\hline & & & Зміша & варіант & БАР & & & & & \\
\hline Кількість слів на літеру «К» & & $16,5 \pm 5$, & $16,0(11,0$ & 18,2 & $, 1 / 17,5(13$ & $23,0)$ & & $4 \pm 4,8 / 12,0$ & $0-18,0)$ & $>0,05$ \\
\hline Кількість слів на літеру «П» & & $14,5 \pm 5$ & $15,0(9,0$ & 16,2 & , / / 16,0 (11 & $21,0)$ & & $4 \pm 4,8 / 10$ & $-16,0)$ & $>0,05$ \\
\hline Кількість слів «Чоловічі імена» & & $15,4 \pm 5$ & $15,0(10,0$ & 17,0 & $, 8 / 16,5(12$ & $22,0)$ & & $4 \pm 4,8 / 11,0$ & $0-17,0)$ & $>0,05$ \\
\hline Кількість слів «Фрукти/меблі» & & $13,9 \pm 5$ & $14,0(9,0$ & 15,5 & $, 3 / 15,0(11$ & $20,0)$ & & $0 \pm 4,3 / 10$, & $-15,0)$ & $>0,05$ \\
\hline & Результс & порівнян & показник & ж групал & за клінічни & аріанто & $\mathrm{M} \Pi$ & БАР & & \\
\hline & & & & & и, що порів & ЮТься & & & & \\
\hline & & разом & & & чоловіки & & & & жінки & \\
\hline Показник & 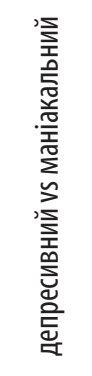 & 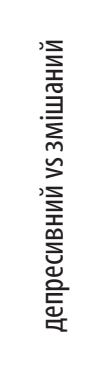 & 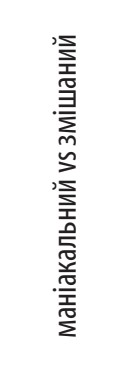 & 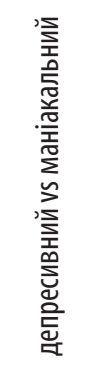 & 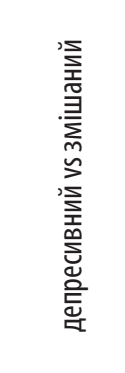 & 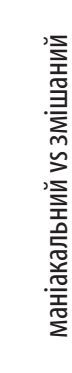 & & 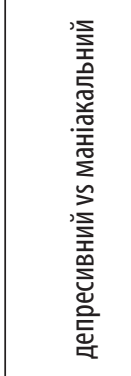 & 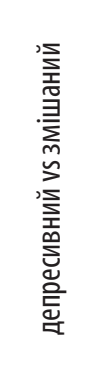 & 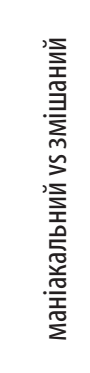 \\
\hline Кількість слів на літеру «К» & $<0,01$ & $>0,05$ & $<0,05$ & $<0,01$ & $>0,05$ & $>0,0$ & & $<0,01$ & $>0,05$ & $>0,05$ \\
\hline Кількість слів на літеру «П» & $<0,01$ & $>0,05$ & $<0,01$ & $<0,01$ & $>0,05$ & $>0,0$ & & $<0,01$ & $>0,05$ & $>0,05$ \\
\hline Кількість слів «Чоловічі імена» & $<0,01$ & $>0,05$ & $<0,05$ & $<0,01$ & $>0,05$ & $>0,0$ & & $<0,01$ & $>0,05$ & $>0,05$ \\
\hline Кількість слів «Фрукти/меблі» & $<0,01$ & $>0,05$ & $<0,01$ & $<0,01$ & $>0,05$ & $>0,0$ & & $<0,01$ & $>0,05$ & $>0,05$ \\
\hline
\end{tabular}


тичну вербальну швидкість: середнє значення показника за субтестом кількості слів «Чоловічі імена» у всіх хворих склало 13,1 22,6 слів, у чоловіків - відповідно $12,8 \pm 3,0$ слів, у жінок - 13,3 22,4 слів; середнє значення за субтестом кількості слів «Фрукти/меблі» склало у

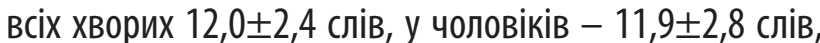
у жінок - 12,1 22,1 слів. Розбіжності у показниках між чоловіками та жінками статистично незначущі.

Низькі показники фонетичної та семантичної вербальної швидкості у хворих з депресивним варіантом ПЕ БАР відображують загальні явища брадипсихізму і сповільнення моторної активності, ригідності мислення та швидкої втомлюваності, притаманних депресивному стану. При цьому кількість помилок (повторно названих слів, а також слів, що позначають предмети або імена, що не належать до даної категорії) у цих хворих була незначною.

На противагу, у хворих з маніакальним варіантом ПЕ БАР швидкість виконання тесту була високою, кількість названих слів була значною, однак, загальний результат тесту виявився гіршим за рахунок численних помилок (повторних назв одних і тих же слів, а також предметів, що не належать до вказаної категорії). Так, середня кількість слів у субтесті кількості слів на літеру «К» у всіх хворих склала 21,7 $\pm 5,7$ слів, у чоловіків $-22,5 \pm 5,7$ слів, у жінок - 20,3 26,0 слів; у субтесті кількості слів на літеру «П» середнє значення у всіх хворих склало 20,3 $\pm 5,6$

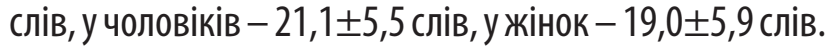

Показники семантичної вербальної швидкості у хворих з маніакальним варіантом ПЕ БАР такожє більшими, ніж при депресивному варіанті, але вони також погіршуються внаслідок численних помилок. Середнє значення за субтестом кількості слів «Чоловічі імена» у всіх хворих склало 20,5 $\pm 5,4$ слів, у чоловіків - 21,2 $\pm 5,2$ слів, у жінок - 19,1 55,7 слів; за субтестом кількості слів «Фрукти/ меблі» у всіх хворих склало 19,5 $\pm 5,4$ слів, у чоловіків $20,2 \pm 5,2$ слів, у жінок - 18,1 $\pm 5,7$ слів. Розбіжності між чоловіками та жінками за всіма субтестами статистично незначущі ( $p>0,05)$. Такі показники зумовлені поєднанням 3 одного боку високої швидкості психічних процесів та прискорення моторної активності, а з іншого боку нестійкістю ментальних процесів та їх хаотичністю, труднощами концентрації та утримання фокусу уваги, притаманними маніакальному стану.

У хворих зі змішаним варіантом ПЕ БАР показники вербальної швидкості займають проміжне положення між тими, які виявлені у хворих з депресивним і маніакальним варіантами.

Так, середнє значення показника за субтестом кількості слів на літеру «К» у всіх хворих цієї групи склало
16,5 $\pm 5,6$ слів, у чоловіків - відповідно 18,2 $\pm 6,1$ слів, у жінок - відповідно 14,4 44,8 слів; за субтестом кількості слів на літеру «П» - у всіх хворих відповідно 14,5 $\pm 5,4$ слів, у чоловіків - 16,2 $\pm 5,7$ слів, ужінок - 12,4 $\pm 4,8$ слів; за субтестом кількості слів «Чоловічі імена» у всіх хворих - відповідно 15,4 $\pm 5,4$ слів, у чоловіків - 17,0 $\pm 5,8$ слів, у жінок - 13,4 4,8 слів; за субтестом кількості слів «Фрукти/меблі» у всіх хворих - відповідно 13,9 $\pm 5,0$

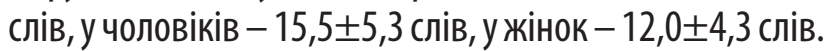
Розбіжності у показниках за всіма субтестами між чоловіками та жінками статистично незначущі $(p>0,05)$.

Показники вербальної швидкості у хворих зі змішаним варіантом ПЕ БАР відображують складний характер змін у психічній сфері, що поєднують полярні афективні переживання, швидку зміну емоційного стану та нестабільність психічних процесів.

При порівнянні груп з різними варіантами ПЕ БАР значущі розбіжності були виявлені для субтесту кількості слів на літеру «К» між групами 3 депресивним та маніакальним варіантами для всіх хворих $(p<0,01)$, для чоловіків $(p<0,01)$ та жінок $(p<0,01)$; між групами 3 маніакальним та змішаним варіантом - для всіх хворих $(p<0,05)$. Для субтесту кількості слів на літеру «П» значущі розбіжності виявлені між групами 3 депресивним та маніакальним варіантами для всіх хворих $(p<0,01)$, для чоловіків $(p<0,01)$ та жінок $(p<0,01)$; між групами 3 маніакальним та змішаним варіантом - для всіх хворих $(p<0,01)$. Для субтесту кількості слів «Чоловічі імена» значущі розбіжності виявлені між групами 3 депресивним та маніакальним варіантами для всіх хворих $(p<0,01)$, для чоловіків $(p<0,01)$ та жінок $(p<0,01)$; між групами 3 маніакальним та змішаним варіантом для всіх хворих $(p<0,05)$. Для субтесту кількості слів «Фрукти/меблі» значущі розбіжності виявлені між групами 3 депресивним та маніакальним варіантами для всіх хворих $(p<0,01)$, для чоловіків $(p<0,01)$ та жінок $(p<0,01)$; між групами 3 маніакальним та змішаним варіантом - для всіх хворих $(p<0,01)$.

Виявлені особливості когнітивних порушень у хворих на ПЕ БАР узгоджуються 3 психопатологічними проявами в афективній сфері. Зокрема, погіршення показників виконання тесту семантичної і фонемної швидкості відбивають стан брадипсихізму, притаманний хворим з депресивним варіантом ПЕ БАР, при якому виявляються сповільнений темп мислення, труднощі концентрації уваги, моторна загальмованість, погіршення операціональних можливостей, швидка виснажуваність і зниження енергетичного потенціалу. При маніакальному варіанті ПЕ БАР виявлено найвищі показники вербальної швидкості серед усіх досліджених 
груп, однак при цьому підвищена швидкість ментальних процесів значною мірою нівелюється значною кількістю помилок при виконанні тесту, яких припускаються хворі внаслідок хаотичності ментальної діяльності, нестійкості і розсіювання уваги, важкості утримання фокусу уваги. Змішаний варіант ПЕ БАР характеризується проміжними характеристиками вербальної швидкості між депресивним і маніакальним варіантами, що пояснюється поліморфністю афективної симптоматики, швидкою змінністю фаз та нестабільністю стану у хворих цієї групи.

Перспективи подальших досліджень пов'язані 3 розробкою на підставі одержаних даних сучасних підходів до прогнозування, лікування, реабілітації та профілактики когнітивних порушень при БАР.

\section{Висновки}

1. Хворим з первинним епізодом біполярного афективного розладу притаманні низькі показники вербальної швидкості, що є відображенням загальних когнітивних порушень при біполярному розладі.

2. Характеристики вербальної швидкості значною мірою зумовлені клінічним варіантом первинного епі- зоду - депресивним, маніакальним або змішаним. При депресивному варіанті показники вербальної швидкості $\epsilon$ найгіршими 3 усіх груп внаслідок притаманних депресивному стану брадипсихізму, моторній загальмованості і ригідності ментальних процесів. При маніакальному варіанті показники вербальної швидкості $\epsilon$ найкращими з усіх груп, однак, вони знижуються за рахунок численних помилок, пов'язаних з труднощами концентрації і нестійкістю уваги та хаотичністю ментальних процесів. При змішаному варіанті показники вербальної швидкості знижені за рахунок впливу складної поліморфної симптоматики зі швидкою зміною стану.

3. Гендерні відмінності у характеристиках вербальної швидкості хворих з первинним епізодом біполярного афективного розладу не виражені.

4. Виявлені закономірності можуть бути використані для раннього виявлення і прогнозування когнітивних порушень при біполярному афективному розладі, а також при розробці лікувально-реабілітаційних і профілактичних заходів при цій патології.

\section{ЛITEPATYPA}

1. Hayes J.F. A systematic review and meta-analysis of premature mortality in bipolar affective disorder / J.F. Hayes, J. Miles, K. Walters, [et al.] // Acta Psychiatrica Scandinavica. - 2015. - Vol. 131(6). - P. 417-425. PMID: 25735195 PMCID: PMC4939858 D0I: 10.1111/acps.12408

2. Patel R. Delays before diagnosis and initiation of treatment in patients presenting to mental health services with bipolar disorder / R. Patel, H. Shetty, R. Jackson, [et al.] // PLoS One. - 2015. - Vol. 10. - P. 126-129. PMID: 25992560 PMCID: PMC4439113 D0I: 10.1371/journal.pone.0126530

3. Forty L. Comorbid medical illness in bipolar disorder / L. Forty, A. Ulanova, L. Jones, [et al.] // N. British J. of Psychiatry. - 2014. - Vol. 205. - P. 465-472. PMID: 25359927 PMCID: PMC4248234 D0l: 10.1192/bjp.bp.114.152249

4. Sam S.P. Stressful Life Events and Relapse in Bipolar Affective Disorder: A CrossSectional Study from a Tertiary Care Center of Southern India / S.P. Sam, A. Nisha, P.J. Varghese // Indian J. of Psychological Medicine. - 2019. - Vol. 41(1). - P. 61-67. PMID: 30783310 PMCID: PMC6337920 DOI: 10.4103/JJPSYM.IJPSYM_113_18

5. Pfennig A. Early recognition and intervention for bipolar disorders: state of research and perspectives (German) / A. Pfennig, C.U. Correll, K. Leopold, [et al.] // Nervenärzt. - 2012. - Vol. 83. - P. 897-902. PMID: 22733382 D0I: 10.1007/s00115012-3589-3

6. Faedda G.L. Clinical risk factors for bipolar disorders: a systematic review of prospective studies / G.L. Faedda, G. Serra, C. Marangoni C., [et al.] // Journal of Affective Disorders. - 2014. - Vol. 168. - P. 314-321. PMID: 25086290 D0I: 10.1016/j. jad.2014.07.013

7. Salvatore P. Antecedents of manic versus other first psychotic episodes in 263 bipolar I disorder patients / P. Salvatore, R.J. Baldessarini, H.M. Khalsa, [et al.] // Acta Psychiatrica Scandinavica. - 2014. - Vol. 129. - P. 275-285. PMCID: PMC3797176 NIHMSID: NIHMS488973 PMID: 23837831 D0I: 10.1111/acps.12170
8. Baldessarini R.J. First-episode types in bipolar disorder: predictive associations with laterillness / R.J. Baldessarini, L. Tondo, C. Visioli // Acta Psychiatrica Scandinavica. 2014. - Vol. 129. - P. 383-392. PMID: 24152091 D0l: 10.1111/acps. 12204

9. Rowland T.A. Epidemiology and risk factors for bipolar disorder / T.A. Rowland, S. Marwaha // Therapeutic Advances in Psychopharmacology. - 2018. - Vol. 8(9). P. 251-269. PMID: 30181867 PMCID: PMC6116765 D0I: 10.1177/2045125318769235

10. Zhu Y. The Relationship Between Cognitive Dysfunction and Symptom Dimensions Across Schizophrenia, Bipolar Disorder, and Major Depressive Disorder // Y. Zhu, F.Y. Womer, H. Leng, [et al.] // Front Psychiatry. - 2019. - Vol. 10. - P. 253. PMID: 31105603 PMCID: PMC6498739 D0I: 10.3389/fpsyt.2019.00253

11. Solé B. Cognitive Impairment in Bipolar Disorder: Treatment and Prevention Strategies / B. Solé, E. Jiménez, C. Torrent, [et al.] // Int. J. Neuropsychopharmacol. 2017. - Vol. 20(8). - P. 670-680. PMID: 28498954 PMCID: PMC5570032 D0I: 10.1093/ ijnp/pyx032

12. Lima I.M.M. Cognitive deficits in bipolar disorders: Implications for emotion. I.M.M. Lima, A.D. Peckham, S.L. Johnson // Clin. Psychol. Rev. - 2015. - Vol. 59. P. 126-136. PMID: 29195773 PMCID: PMC6404979 D0I: 10.1016/j.cpr.2017.11.006

13. Chakrabarty T. Cognitive functioning in first episode bipolar I disorder patients with and without history of psychosis / T. Chakrabarty, G. Alamian, J.M. Kozicky, [et al.] // J. of Affective Disorders. - 2018. - Vol. 227. - P. 109-116. PMID: 29055258 DOl: 10.1016/j.jad.2017.10.003

14. Sanches M. The Management of Cognitive Impairment in Bipolar Disorder: Current Status and Perspectives / M. Sanches, I.E. Bauer, J.F. Galvez, [et al.] //Am. J. Ther. - 2015. - Vol. 22(6). - P. 477-486. PMID: 25383489 PMCID: PMC4424179 DOI: 10.1097/MJT.0000000000000120

15. Murri B.M. Cognitive impairment in late life bipolar disorder: Risk factors and clinical outcomes / B.M. Murri, M. Respino, L. Proietti, [et al.] // J. of Affective Disorders. 2019. - Vol. 257. - P. 166-172. PMID: 31301619 D0I: 10.1016/j.jad.2019.07.052 
2020. Випуск/Issue 13

\section{REFERENCES}

1. Hayes J.F., Miles J., Walters K., [et al.] A systematic review and meta-analysis of premature mortality in bipolar affective disorder. Acta Psychiatrica Scandinavica. 2015. Vol. 131(6), pp. 417-425. D0l: 10.1111/acps.12408

2. Patel R., Shetty H., Jackson R., [et al.] Delays before diagnosis and initiation of treatment in patients presenting to mental health services with bipolar disorder. PLoS One. 2015. Vol. 10, pp. 126-129. D0I: 10.1371/journal.pone.0126530

3. Forty L., Ulanova A., Jones L., [et al.] Comorbid medical illness in bipolar disorder. British Journal of Psychiatry. 2014. Vol. 205, pp. 465-472. D0I: 10.1192/bjp. bp. 114.152249

4. Sam S.P., Nisha A., Varghese P.J. Stressful Life Events and Relapse in Bipolar Affective Disorder: A Cross-Sectional Study from a Tertiary Care Center of Southern India. Indian Journal of Psychological Medicine. 2019. Vol. 41(1), pp. 61-67. D0I: 10.4103/IJPSYM.IJPSYM_113_18

5. Pfennig A., Correll C.U., Leopold K., [et al.] Early recognition and intervention for bipolar disorders: state of research and perspectives (German). Nervenärzt. 2012 Vol. 83, pp. 897-902. D0I: 10.1007/s00115-012-3589-3

6. Faedda G.L., Serra G., Marangoni C., [et al.] Clinical risk factors for bipolar disorders: a systematic review of prospective studies. Journal of Affective Disorders. 2014. Vol. 168, pp. 314-321. D0I: 10.1016/j.jad.2014.07.013

7. Salvatore P., Baldessarini R.J., Khalsa H.M., [et al.] Antecedents of manic versus other first psychotic episodes in 263 bipolar I disorder patients. Acta Psychiatrica Scandinavica. 2014. Vol. 129, pp. 275-285. D0I: 10.1111/acps.12170

8. Baldessarini R.J., Tondo L., Visioli C. First-episode types in bipolar disorder: predictive associations with later illness. Acta Psychiatrica Scandinavica. 2014. Vol. 129, pp. 383-392. D0l: 10.1111/acps.12204
9. Rowland T.A., Marwaha S. Epidemiology and risk factors for bipolar disorder. Therapeutic Advances in Psychopharmacology. 2018. Vol. 8(9), pp. 251-269. DOI: 10.1177/2045125318769235

10. Zhu Y., Womer F.Y., Leng H., [et al.] The Relationship Between Cognitive Dysfunction and Symptom Dimensions Across Schizophrenia, Bipolar Disorder, and Major Depressive Disorder. Front Psychiatry. 2019. Vol. 10, pp. 253. D0I: 10.3389/ fpsyt.2019.00253

11. Solé B., Jiménez E., Torrent C., [et al.] Cognitive Impairment in Bipolar Disorder: Treatment and Prevention Strategies. Int J Neuropsychopharmacol. 2017. Vol. 20(8), pp. 670-680. D0l: 10.1093/ijnp/pyx032

12. Lima I.M.M., Peckham A.D., Johnson S.L. Cognitive deficits in bipolar disorders: Implications for emotion. Clin Psychol Rev. 2015. Vol. 59, pp. 126-136. D0I: 10.1016/j. cpr.2017.11.006

13. Chakrabarty T., Alamian G., Kozicky J.M., [et al.] Cognitive functioning in first episode bipolar I disorder patients with and without history of psychosis. Journal of Affective Disorders. 2018. Vol. 227, pp. 109-116. D0I: 10.1016/j.jad.2017.10.003

14. Sanches M., Bauer I.E., Galvez J.F., [et al.] The Management of Cognitive Impairment in Bipolar Disorder: Current Status and Perspectives. Am J Ther. 2015. Vol. 22(6), pp. 477-486. D0I: 10.1097/MJT.0000000000000120

15. Murri B.M., Respino M., Proietti L., [et al.] Cognitive impairment in late life bipolar disorder: Risk factors and clinical outcomes. Journal of Affective Disorders. 2019. Vol. 257, pp. 166-172. D0I: 10.1016/j.jad.2019.07.052

\section{ХАРАКТЕРИСТИКИ ВЕРБАЛЬНОЙ БЕГЛОСТИ У БОЛЬНЫХ С ПЕРВИЧНЫМ ЭПИЗОДОМ БИПОЛЯРНОГО АФФЕКТИВНОГО РАССТРОЙСТВА}

\section{Мисула \\ Юрий Игоревич}

\author{
Тернопольский национальный медицинский университет им. И.Я. Горбачевского М30 \\ Украины, ул. Майдан Воли, 1, г. Тернополь, Украина, 46001 \\ yuramysula@gmail.com; ORCID ID: 0000-0001-7443-5304
}

Проведено исследование с использованием теста вербальной беглости 153 больных с первичным эпизодом биполярного аффективного расстройства: с преобладанием депрессивной симптоматики (44 мужчины и 75 женщин), с преобладанием маниакальной симптоматики (15 мужчин и 8 женщин) и с одновременным наличием депрессивной и маниакальной симптоматики или с быстрым изменением фаз (6 мужчин и 5 женщин).

Выявлено значительное ухудшение выполнения теста у больных с депрессивным вариантом по фонетической и семантической вербальной беглости: среднее количество слов на букву «К» 60 сек. у всех больных 14,1 22,7 слов,

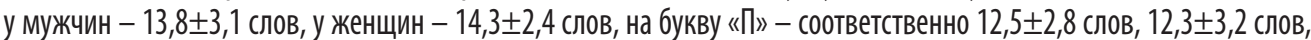

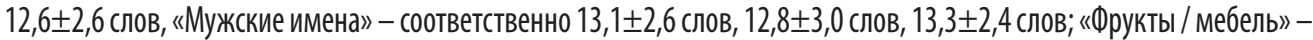

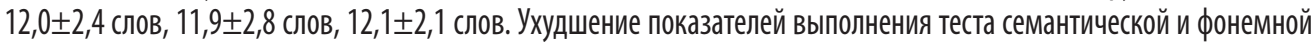
скорости отражают состояние брадипсихизма, присущее больным с депрессивным вариантом, при котором проявляются замедленный темп мышления, трудности концентрации внимания, моторная заторможенность, ухудшение операциональных возможностей, быстрая истощаемость и снижение энергетического потенциала. У больных с маниакальным вариантом высокая скорость выполнения теста нивелируется большим количеством ошибок вследствие хаотичности ментальной деятельности, неустойчивости и рассеивания внимания, сложности удержания фо-

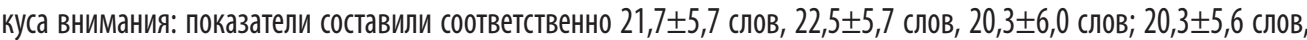

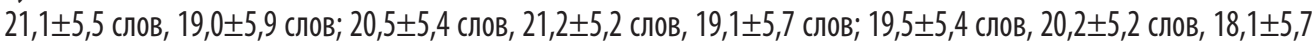
слов. У больных со смешанным вариантом показатели вербальной беглости снижены за счет влияния сложной полиморфной симптоматики с быстрым изменением состояния: соответственно 16,5 $\pm 5,6$ слов, 18,2 $\pm 6,1$ слов, 14,4 44,8 слов; $14,5 \pm 5,4$ слов, 16,2 $\pm 5,7$ слов, $12,4 \pm 4,8$ слов; $15,4 \pm 5,4$ слов, $17,0 \pm 5,8$ слов, $13,4 \pm 4,8$ слов; $13,9 \pm 5,0$ слов, $15,5 \pm 5,3$ слов, 12,0 4,3 слов. Различия в показателях по всем субтестам во всех группах между мужчинами и женщинами статистически незначимы ( $p>0,05)$.

Ключевые слова: биполярное аффективное расстройство, первичный эпизод, вербальная беглость. 


\title{
CHARACTERISTICS OF VERBAL FLUENCY IN PATIENTS WITH A PRIMARY EPISODE OF BIPOLAR AFFECTIVE DISORDER
}

Mysula Yuriy

\author{
Ivan Horbachevsky Ternopil National Medical University, Maydan Voli str., 1, \\ Ternopil, Ukraine, 46001 \\ yuramysula@gmail.com; ORCID ID: 0000-0001-7443-5304
}

A study was conducted using the verbal fluency test of 153 patients with a primary episode of bipolar affective disorder: with prevalence of depressive symptoms (44 men and 75 women), with prevalence of manic symptoms (15 men and 8 women), and with simultaneous presence of depressive symptoms and manic symptoms phase change (6 men and 5 women).

Significant impairment of test performance in patients with depression with respect to phonetic and semantic verbal fluency was revealed: the average number of words per letter " $K$ " per 60 sec. in all patients $14,1 \pm 2,7$ words, in men $-13,8 \pm 3,1$ words, in women $-14,3 \pm 2,4$ words, on the letter " $\mathrm{P}$ " $-12,5 \pm 2,8$ respectively words, $12.3 \pm 3.2$ words, $12.6 \pm 2.6$ words, "Male Names" - 13.1 \pm 2.6 words respectively, 12.8 \pm 3.0 words, $13.3 \pm 2,4$ words; "Fruits / furniture" - 12.0 2.4 words, $11.9 \pm 2.8$ words, 12.1 \pm 2.1 words. Deterioration in the performance of semantic and phonemic verbal fluency test reflects the state of bradypsychism inherent in patients with depressive variant, which manifests a slow thinking rate, difficulty concentrating attention, motor inhibition, deterioration of operational capacity, rapid exhaustion. In patients with a maniacal variant, the high speed of the test is offset by a large number of errors due to the chaotic mental activity, instability and scattering of attention, the difficulty of maintaining focus of attention: the indicators were respectively $21.7 \pm 5.7$ words, $22.5 \pm 5.7$ words, $20,3 \pm 6.0$ words; $20.3 \pm 5.6$ words, $21.1 \pm 5.5$ words, $19.0 \pm 5.9$ words; $20.5 \pm 5.4$ words, $21.2 \pm 5.2$ words, $19.1 \pm 5.7$ words; 19.5 \pm 5.4 words, $20.2 \pm 5.2$ words, $18.1 \pm 5.7$ words. In patients with mixed variants, the indicators of verbal fluency are reduced due to the influence of complex polymorphic symptoms with rapid change of state: respectively $16.5 \pm 5.6$ words, 18.2 \pm 6.1 words, $14.4 \pm 4.8$ words; $14.5 \pm 5.4$ words, $16.2 \pm 5.7$ words, $12.4 \pm 4.8$ words; $15.4 \pm 5.4$ words, $17.0 \pm 5.8$ words, $13.4 \pm 4.8$ words; $13.9 \pm 5.0$ words, $15.5 \pm 5.3$ words, $12.0 \pm 4.3$ words. The differences in scores across all subtests in all groups between men and women are statistically insignificant $(\mathrm{p}>0.05)$.

Keywords: bipolar affective disorder, primary episode, verbal fluency. 